\title{
Cheese Manufacture with Milk with Elevated Conjugated Linoleic Acid Levels Caused by Dietary Manipulation
}

\author{
M. Coakley, ${ }^{\star}$ E. Barrett, ${ }^{\star} \dagger$ J. J. Murphy, $\ddagger$ R. P. Ross, ${ }^{\star} \dagger$ R. Devery, $\S$ and C. Stanton ${ }^{\star} \dagger^{1}$ \\ *Teagasc, Moorepark Food Research Centre, Fermoy, Co. Cork, Ireland \\ †Alimentary Pharmabiotic Centre, University College, Cork, Ireland \\ ¥Teagasc, Moorepark Dairy Production Research Centre, Fermoy, Co. Cork, Ireland \\ $\S N a t i o n a l$ Institute for Cellular Biotechnology, Dublin City University, Dublin, Ireland
}

\begin{abstract}
The objective of this study was to assess the effect of dietary supplementation of cows on pasture with sunflower oil for conjugated linoleic acid (cis-9, trans-11 CLA) enrichment of milk, for the production of CLAenriched cheese. A group of 40 autumn-calving dairy cows were assigned to either a control group (indoor feeding on grass silage ad libitum and $6 \mathrm{~kg} / \mathrm{d}$ of a typical indoor concentrate) or an experimental group (on pasture, being fed $6 \mathrm{~kg}$ of a supplement containing $100 \mathrm{~g} /$ $\mathrm{kg}$ of sunflower oil per d). These diets were fed for 16 $\mathrm{d}$, during which time milk was collected for pilot-scale hard cheese manufacture. The pasture-based diet with sunflower oil resulted in a significant effect on the milk fatty acid CLA content. The concentration of cis-9, trans-11 CLA in the milk produced from cows on this diet increased to $2.22 \mathrm{~g} / 100 \mathrm{~g}$ of fatty acid methyl esters (FAME) after $14 \mathrm{~d}$, compared with $0.46 \mathrm{~g} / 100 \mathrm{~g}$ of FAME in milk produced on the control indoor diet. The content of cis-9, trans-11 CLA in the cheese manufactured from the indoor control milk was $0.78 \mathrm{~g} / 100 \mathrm{~g}$ of FAME and that from the pasture-based sunflower oil milk was 1.93 $\mathrm{g} / 100 \mathrm{~g}$ of FAME. The cheese was assessed during the ripening period and CLA concentrations were stable throughout the 6 mo of ripening. Other cheese variables (microbiology, composition, flavor, free AA) were monitored during the ripening period, and the cheese with the elevated CLA concentrations compared favorably with the control cheese. Thus, a pasture-based diet supplemented with an oil source rich in linoleic acid resulted in an enhanced CLA content of bovine milk fat, compared with an indoor grass silage-based diet.
\end{abstract}

Key words: conjugated linoleic acid, sunflower oil, cheese, dairy cow

Received September 11, 2006.

Accepted January 23, 2007.

${ }^{1}$ Corresponding author: catherine.stanton@teagasc.ie

\section{INTRODUCTION}

Conjugated linoleic acid (CLA), a natural component of milk fat, is produced in the rumen during the formation of stearic acid because of the microbial biohydrogenation of polyunsaturated fatty acids (PUFA), such as linoleic acid and linolenic acid (Kepler et al., 1966). Trans-vaccenic acid (C18:1 trans-11; TVA) is also formed as an intermediate and can act as a substrate for the bovine mammary $\Delta^{9}$-desaturase enzyme (Griinari et al., 2000). Conjugated linoleic acid has been shown to exert positive effects on many aspects of human health, including antiatherogenic action, enhancement of immunological function, reduction of body fat, and anticancer activity (Wahle et al., 2004). The presence of CLA in humans is mainly associated with ingestion of foods rich in CLA (foods from milk and meat from ruminant animals) rather than the endogenous synthesis of CLA (Parodi, 2003). It is thus reasonable to suggest that to increase CLA levels in humans, it should be ingested in food products.

To naturally enrich CLA concentrations in dairy products for use as functional foods, the concentration of CLA in milk should first be elevated through dietary manipulation. With this in mind, numerous studies have been undertaken in an attempt to increase the vaccenic acid (CLA precursor) and CLA content in milk fat (for reviews see Stanton et al., 2003, and Khanal and Olson, 2004). To date, studies have indicated that the diet of the ruminant animal has a significant effect on CLA levels in milk fat. Lipid substrates that have been added to the bovine diet and proven to be successful for enhancing the CLA concentration in milk fat include plant oils rich in PUFA and fish oils rich in long-chain PUFA, the former through enhancement of biohydrogenation substrates, and the latter by affecting pathways of rumen biohydrogenation (Chilliard et al., 1999; Dhiman et al., 2000). Ruminant ingestion of plant oils rich in linoleic acid, including soybean oil (Khanal et al., 2005; Lynch et al., 2005) and sunflower oil (Kelly et al., 1998; Jones et al., 2005), has increased milk fat CLA concentrations effectively. In addition to increas- 
ing the CLA content of milk fat, added linoleic acid is thought to interfere with the biohydrogenation of TVA in the rumen, thus leading to its accumulation and availability for conversion to CLA in the mammary gland via $\Delta^{9}$-desaturase. Oils rich in linolenic acid, such as linseed oil, result in increased levels of TVA, leading to CLA production in the mammary gland. Lock and Garnsworthy (2002) studied a dietary regimen in which concentrations of linoleic and linolenic acids were altered. The concentration of the cis-9, trans-11 CLA isomer in milk fat was greatest when both linoleic and linolenic acids were high in the diet. Thus, supplementing cows' diets with plant oils rich in linoleic acid or linolenic acid or both result in elevated concentrations of cis-9, trans-11 CLA in the milk fat.

Studies have also confirmed that pasture feeding significantly and rapidly increases milk fat CLA concentrations (Kelly et al., 1998). Although the CLA-enriching effect of pasture feeding has not been conclusively characterized, it is thought to be due mainly to the impact on bacteria associated with biohydrogenation and the provision of linolenic acid as a lipid substrate (Griinari and Bauman, 1999). Thus, a combination of pasture feeding and sunflower oil supplementation are used in this study to increase the CLA content of milk fat with a view to producing CLA-enriched milk for the development of naturally enhanced CLA-rich dairy products.

Conjugated linoleic acid concentrations in dairy products vary significantly because of variations in the original raw material, milk (Jiang et al., 1997; Zlatanos et al., 2002). Apart from the characteristics of the raw milk, the amount of CLA in dairy products can be affected by the numerous processing parameters involved in product manufacture, including the type of starter culture used (Aneja and Murthi, 1990; Jiang et al., 1998), the length of ripening, the processing technology (e.g., heat treatments; Shantha et al., 1992; Garcia Lopez et al., 1994), and exposure to air (Shantha et al., 1992; Lin et al., 1998). Conjugated linoleic acid-enriched cheese (Dhiman et al., 1999) and butter (Bauman et al., 2000; Ramaswamy et al., 2001) have previously been manufactured using CLA-enriched milk obtained following dietary supplementation.

Producing milk with elevated CLA concentrations should be more feasible in milk production systems largely based on grazed pasture, such as those in New Zealand, Ireland, and parts of northwestern Europe, than in milk production systems based on nonpasture indoor feeding, given the well-documented CLA-enhancing properties of pasture. However, pasture is not available throughout the year, resulting in seasonal effects on the CLA content of the milk and making it difficult to conform to a minimum CLA level in dairy product labeling. Supplementation of pasture with oil supplements containing high levels of linoleic acid would appear to be a suitable strategy to increase the CLA content of the milk even above that achievable on pasture alone. Thus, the main objectives of this study were to assess the magnitude of the increase in milk fat CLA caused by the feeding of pasture plus sunflower oil compared with a grass silage-based indoor diet, and to determine the cheese-making and ripening characteristics of CLA-enriched and control milk.

\section{MATERIALS AND METHODS}

\section{Experimental Design}

Forty autumn-calving dairy cows were blocked on the basis of calving date and milk yield into pairs and were randomly assigned from within pairs to 2 treatment groups: 1) indoor feeding on grass silage ad libitum and $6 \mathrm{~kg}$ of a typical indoor concentrate (IC), and 2) pasture feeding plus $6 \mathrm{~kg}$ of supplement (PS) containing 100 $\mathrm{g} / \mathrm{kg}$ of sunflower oil (Trilby Trading Ltd., Drogheda, Ireland). The cows had a lactation number of 3.8 (SD 1.35), were $241 \mathrm{~d}$ (SD 31.8) in lactation, and were yielding $23.3 \mathrm{~kg}$ of milk/cow per d (SD 3.26) when treatments commenced. Treatments were imposed for a total of 16 d. The typical IC consisted of (kg/t) 250 barley, 270 unmolassed sugar beet pulp, 170 maize gluten feed, 150 rapeseed meal, 100 soyabean meal, 30 lard, and 30 minerals plus vitamins. The sunflower oil supplement consisted of (kg/t) 670 unmolassed sugar beet pulp, 200 corn gluten feed, 100 sunflower oil, and 30 minerals plus vitamins. Vitamin $\mathrm{E}$ inclusion was 10 -fold greater in the sunflower oil supplement at 150,000 IU/t. The indoor and sunflower oil concentrate supplements contained 195 and $116 \mathrm{~g} / \mathrm{kg}$ of DM of CP, 271 and $410 \mathrm{~g} /$ $\mathrm{kg}$ of DM of NDF, and 105 and $99 \mathrm{~g} / \mathrm{kg}$ of DM of ash, respectively. The grass silage feed contained 162, 623, and $76 \mathrm{~g} / \mathrm{kg}$ of DM of $\mathrm{CP}, \mathrm{NDF}$, and ash, respectively, and had a DM digestibility value of 664 . The pasture offered was composed principally of perennial ryegrass. The mean quantity of grass DM available at the start of each grazing during the experimental period was $2.22 \mathrm{t} / \mathrm{ha}$. It contained 159,400 , and $83 \mathrm{~g} / \mathrm{kg} \mathrm{DM}$ of CP, $\mathrm{NDF}$, and ash, respectively. All cows were on pasture full time for $88 \mathrm{~d}$ before treatments commenced and had received no concentrate supplement for the previous 48 d. Individual milk samples were taken from these cows at the evening milkings on $\mathrm{d} 0,7$, and 14 after treatments commenced. Bulk milk samples for cheese manufacture were taken from both treatment groups on $d$, 14 , and 16 after treatments commenced. 


\section{Milk Fat CLA Analysis}

Fat Extraction from Milk. Individual milk samples were assessed for fatty acid concentration and cis-9, trans-11 CLA concentration. Milk fat samples were obtained as previously described (Murphy et al., 1990), by collecting the cream by centrifugation at $1,000 \times g$ for $20 \mathrm{~min}$ at $4^{\circ} \mathrm{C}$. Following overnight storage at $-20^{\circ} \mathrm{C}$, the cream was heated to $60^{\circ} \mathrm{C}$ for $10 \mathrm{~min}$ and then centrifuged at $1,600 \times g$ for $7 \mathrm{~min}$. The top layer (milk fat) was removed and stored at $-20^{\circ} \mathrm{C}$ under nitrogen prior to methylation.

Methylation of Milk Fat. Milk fat $(\sim 30 \mathrm{mg})$ was methylated in duplicate using acid-catalyzed methylation, as described previously to generate fatty acid methyl esters (FAME; Stanton et al., 1997).

GLC Analysis. Fatty acids were quantified by GLC analysis using a Varian 3400 gas-liquid chromatograph (Varian, Walnut Creek, CA) fitted with a flame-ionization detector. The results were expressed as a percentage of the total FAME present (\% or g/100 g of FAME). Separation of the FAME was performed on a Chrompack CP Sil 88 column (Chrompack, Middlelburg, the Netherlands; dimensions: $100 \mathrm{~m}$ length, $0.25 \mathrm{~mm}$ i.d., $20 \mu \mathrm{m}$ film thickness), using $\mathrm{He}$ as the carrier gas at a pressure of $232 \mathrm{kPa}$. The injector temperature was $225^{\circ} \mathrm{C}$ isothermal, with a hold time of $5 \mathrm{~min}$, and the detector temperature was $250^{\circ} \mathrm{C}$. The column temperature was programmed from an initial temperature of $80^{\circ} \mathrm{C}$ to a final temperature of $200^{\circ} \mathrm{C}$, with an initial delay of $8 \mathrm{~min}$ (hold time), at a rate of $8.5^{\circ} \mathrm{C} / \mathrm{min}$ during each analysis. The column was held at the final temperature of $200^{\circ} \mathrm{C}$ for $77 \mathrm{~min}$ (final hold time). Collected data were recorded and analyzed on a Minichrom PC system (VG Data System, St. George's Court, Altrincham, UK). A certified reference material (CRM164, Community Bureau of Reference, Brussels), which is an anhydrous milk fat standard, was regularly assessed on the gas chromatograph to ensure comparability of columns and accuracy of results.

\section{Samples and Animal Measurements}

Milk yield (kg) was recorded daily at the morning and evening milkings using electronic milk meters (Dairy Master, Causeway, Co. Kerry, Ireland). Milk composition (fat, protein, and lactose) was determined once weekly, from successive morning and evening milkings, by automated infrared analysis with a MilkoScan 203 using the $\mathrm{C}-\mathrm{H}$ stretch for fat measurement (Foss Electric, Hillerød, Denmark; IDF, 2000). Grass was cut with an Agria mower (Agria-Werke GmbH, Mockmuhl, Germany) to $6 \mathrm{~cm}$ and was sampled pregrazing once weekly to determine grass available and grass quality. Samples were analyzed for DM, CP, ash, and NDF. All supple- ments were sampled once weekly and analyzed for DM, $\mathrm{CP}$, and ash.

\section{Analysis of Feedstuffs}

The $\mathrm{CP}, \mathrm{NDF}$, and ash contents of the grass, grass silage, and concentrate supplements were analyzed according to the methods outlined in McNamara et al. (2003). Determination of in vitro DM digestibility was performed by near-infrared spectroscopy using an NIR Systems 6500 spectrophotometer (Perstorp Analytical Incorporated, Silver Spring, MD).

\section{Pilot-Scale Cheese Manufacture}

Pilot-scale cheese was manufactured in triplicate at Moorepark Technology Ltd., from the milk produced on the IC and PS treatments. Milk was collected from a morning and evening milking prior to the cheese making, and was filtered, standardized (fat-to-protein ratio of $0.97: 1$ ), pasteurized, and cooled to $30^{\circ} \mathrm{C}$. Standardization was carried out with skim milk and cream generated from milk supplied by an external commercial milk supplier and not by the cows on trial. On each cheesemaking date (trial A, d 9; trial B, d 14; and trial C, d 16), 2 open vats (IC and PS milk) each containing 300 to $400 \mathrm{~L}$ of pasteurized whole milk were used. A $1.5 \%$ (wt/wt) starter inoculum of commercially available Hansen's cultures (Lactococcus 303 and 227) was added to all vats (Chr. Hansen, Little Island, Cork, Ireland). These starter cultures had been grown separately overnight prior to the cheese making in $10 \%$ (wt/vol) reconstituted skim milk at $23^{\circ} \mathrm{C}$. A 50:50 mix of these starter cultures was inoculated to the cheese milk. Cheese was then manufactured as described by Ryan et al. (1996). After overnight pressing, the cheese was vacuum packed and ripened at $8^{\circ} \mathrm{C}$ for 6 mo. Cheeses manufactured from the IC and PS milk are referred to subsequently as control and elevated-CLA cheese, respectively.

Cheese Microbiology. Cheese was sampled aseptically from each cheese in duplicate at $d 1$, wk 1 , and then monthly up to mo 6. Levels of starter bacteria and nonstarter lactic acid bacteria (NSLAB) in the cheese were enumerated in duplicate as outlined in Ryan et al. (1996).

Cheese Composition. The composition ( $\mathrm{pH}$, fat, protein, salt, and moisture) of the cheese was analyzed at $\sim$ mo 1 (trial A at d 35, trial B at d 30, and trial C at d 28). Grated cheese samples were analyzed for salt by a potentiometric method (IDF, 1988), fat content by the Mojonnier method (IDF, 1986), moisture content by oven drying at $102^{\circ} \mathrm{C}$ (IDF, 1982), and protein content by the Kjeldahl method (IDF, 1993). The $\mathrm{pH}$ was mea- 
Table 1. Yields of milk constituents and milk composition on the indoor grass and silage-based diet (IC) and the outdoor pasture-based diet with added sunflower oil (PS)

\begin{tabular}{|c|c|c|c|c|}
\hline \multirow[b]{2}{*}{ Yield } & \multicolumn{2}{|c|}{ Treatment group } & \multirow[b]{2}{*}{ SEM } & \multirow[b]{2}{*}{$P$-value } \\
\hline & IC & PS & & \\
\hline Milk (kg/d) & 17.3 & 23.5 & 0.47 & $<0.001$ \\
\hline Fat $(g / d)$ & 721 & 760 & 24.4 & 0.291 \\
\hline Protein (g/d) & 552 & 824 & 17.3 & $<0.001$ \\
\hline Lactose $(\mathrm{g} / \mathrm{d})$ & 800 & 1086 & 21.1 & $<0.001$ \\
\hline Fat $(\mathrm{g} / \mathrm{kg})$ & 41.7 & 32.6 & 1.34 & $<0.001$ \\
\hline Protein $(\mathrm{g} / \mathrm{kg})$ & 32.1 & 35.3 & 0.29 & $<0.001$ \\
\hline Lactose $(\mathrm{g} / \mathrm{kg})$ & 46.2 & 46.4 & 0.28 & 0.629 \\
\hline
\end{tabular}

sured using a Radiometer PHM 82 standard $\mathrm{pH}$ meter (Radiometer, Copenhagen, Denmark) on cheese slurry prepared by blending $12 \mathrm{~mL}$ of distilled $\mathrm{H}_{2} \mathrm{O}$ with $20 \mathrm{~g}$ of grated cheese.

Fat Extraction from Cheese and Preparation of FAME for GLC Analysis. Fat was extracted from cheese with an ammonium thiocyanate solution as follows. The cheese sample was finely grated and $15 \mathrm{~g}$ of cheese was weighed and mixed with $25 \mathrm{~g}$ of ammonium thiocyanate solution ( $30 \% \mathrm{wt} / \mathrm{vol}$, freshly prepared). The mixture was placed in a water bath at $60^{\circ} \mathrm{C}$ for 1 $\mathrm{h}$ with occasional shaking. After removal from the water bath, the mixture was centrifuged at $538 \times g$ for $20 \mathrm{~min}$. The fat layer was removed and stored at $4^{\circ} \mathrm{C}$ overnight.
Fatty acid methyl esters of the total extracted fat were prepared as described above. Cheese was sampled for fatty acid analysis at d 1, wk 1 , and mo 1 to 6 .

Grading of the Cheese. Previously unopened blocks of cheese were assessed by a commercial grader from a local cheese plant at mo 6 of ripening. The maximum scores available for flavor and body were 45 and 35, respectively. For the cheese to be described as acceptable, the minimum scores required for flavor and body were 37 and 30 , respectively.

\section{Statistical Analysis}

Animal performance was measured on $d 16$. The performance data in the calendar week (Monday to Sunday) corresponding to $\mathrm{d} 6$ to 12 on treatment, inclusive, were analyzed to compare treatments. Milk yield, constituent yields, and milk composition were analyzed using the GLM procedure (SAS Institute, Inc., Cary, NC). The least squares means reported here were adjusted for block, lactation number, calving date, and the appropriate preexperimental variable. Fatty acids in individual cow milk samples on d 14 were analyzed by the GLM procedure of SAS, and the least squares means reported here were adjusted for block and $d 0$ values. Fatty acids were analyzed in cheese samples taken on d 1, 7 (wk 1), 28 (mo 1), 56 (mo 2), 84 (mo 3),

Table 2. Effect of treatment on the milk fatty acid composition of cows indoors on the control diet (IC) and cows outdoors on pasture receiving sunflower oil supplementation (PS), at d 14

\begin{tabular}{|c|c|c|c|c|}
\hline \multirow[b]{2}{*}{ Fatty acid (g/100 g of FAME) } & \multicolumn{2}{|c|}{ Treatment group } & \multirow[b]{2}{*}{ SEM } & \multirow[b]{2}{*}{$P$-value ${ }^{1}$} \\
\hline & IC & PS & & \\
\hline $\mathrm{C} 4: 0$ & 1.46 & 1.51 & 0.04 & 0.396 \\
\hline $\mathrm{C} 6: 0$ & 1.50 & 1.22 & 0.04 & $<0.01$ \\
\hline $\mathrm{C} 8: 0$ & 1.18 & 0.85 & 0.04 & $<0.001$ \\
\hline C10:0 & 2.92 & 1.86 & 0.08 & $<0.001$ \\
\hline $\mathrm{C} 12: 0$ & 3.56 & 2.30 & 0.08 & $<0.001$ \\
\hline C14:0 & 12.82 & 9.35 & 0.17 & $<0.001$ \\
\hline C14:1 total & 1.45 & 1.41 & 0.05 & 0.537 \\
\hline $\mathrm{C} 15: 0$ & 1.66 & 1.13 & 0.03 & $<0.001$ \\
\hline $\mathrm{C} 16: 0$ & 35.59 & 21.62 & 0.43 & $<0.001$ \\
\hline C16:1 total & 2.30 & 2.09 & 0.04 & $<0.01$ \\
\hline C17:0 & 0.60 & 0.61 & 0.01 & 0.807 \\
\hline $\mathrm{C} 17: 1$ & 0.52 & 0.35 & 0.01 & $<0.001$ \\
\hline C18:0 & 7.51 & 12.63 & 0.13 & $<0.001$ \\
\hline $\mathrm{C} 18: 1$ trans $-9+18: 1$ trans $-11^{2}$ & 1.37 & 8.05 & 0.25 & $<0.001$ \\
\hline $\mathrm{C} 18: 1$ trans $-13+18: 1$ cis $-9^{2}$ & 18.27 & 25.63 & 0.28 & $<0.001$ \\
\hline C18:2 cis-9, cis-12 linoleic acid & 1.14 & 2.53 & 0.07 & $<0.001$ \\
\hline $\mathrm{C} 20: 0$ & 0.12 & 0.10 & 0.00 & $<0.01$ \\
\hline C18:3 cis-9, cis-12, cis-15 linolenic acid & 0.53 & 0.53 & 0.01 & 0.740 \\
\hline C18:2 cis-9, trans-11 CLA & 0.46 & 2.22 & 0.04 & $<0.001$ \\
\hline Other fatty acids & 4.38 & 4.50 & 0.14 & 0.633 \\
\hline
\end{tabular}

\footnotetext{
${ }^{1}$ The fatty acid levels have been statistically adjusted for block effects and d 0 levels of fatty acids.

${ }^{2}$ The peaks generated on the gas chromatograph for C18:1 trans-9 and C18:1 trans-11 vaccenic acid are very close and are thus difficult to separate accurately, so to avoid subjectivity on the division of the peaks, these 2 peaks are counted as one, with C18:1 trans-11 vaccenic acid being the major fatty acid present. This also occurred with C18:1 trans-13 and C18:1 cis-9 oleic acid, with C18:1 cis-9 oleic acid being the major peak.
} 
Table 3. Fat, protein, and lactose concentrations ${ }^{1}$ in bulk milk from control (IC) and supplemented (PS) diets following collection (Pre-Std) and at the start of cheese making, following standardization (Post-Std)

\begin{tabular}{|c|c|c|c|c|c|c|}
\hline \multirow[b]{2}{*}{ Treatment $^{2}$} & \multicolumn{2}{|c|}{ Fat $(\%)$} & \multicolumn{2}{|c|}{ Protein (\%) } & \multicolumn{2}{|c|}{ Lactose $(\%)$} \\
\hline & Pre-Std & Post-Std & Pre-Std & Post-Std & Pre-Std & Post-Std \\
\hline IC & $3.81 \pm 0.28$ & $3.11 \pm 0.10$ & $3.14 \pm 0.12$ & $3.21 \pm 0.10$ & $4.51 \pm 0.18$ & $4.58 \pm 0.18$ \\
\hline PS & $3.15 \pm 0.28$ & $3.29 \pm 0.09$ & $3.40 \pm 0.10$ & $3.40 \pm 0.10$ & $4.62 \pm 0.06$ & $4.62 \pm 0.07$ \\
\hline
\end{tabular}

112 (mo 4), 140 (mo 5), and 168 (mo 6) after manufacture using the GLM repeated measures procedure of SAS.

\section{RESULTS AND DISCUSSION}

\section{Production Data}

The mean values for the major milk constituents are detailed in Table 1. Yields of milk, protein, and lactose were greater $(P<0.001)$ for cows outdoors on the pasture-based sunflower oil treatment than those indoors on the grass silage-based treatment. Fat yield was unaffected by the treatments, but fat concentration was reduced $(P<0.001)$ in the PS compared with the IC $(41.7$ and $32.6 \mathrm{~g}$ of fat $/ \mathrm{kg}$ of milk, respectively) treatment. Milk fat depression has previously been reported as a result of supplementation of the diet with oilseeds, fish oil, and high concentrate levels (for reviews see Davis and Brown, 1970; Bauman and Griinari, 2001, 2003). In the current experiment, the depression in milk fat concentration resulted from a dilution effect because of increased milk volume production. The milk protein concentration was higher $(P<0.001)$ on PS, and the lactose concentration was similar on both treatments. Such production differences have been observed previously, in which grass silage and the grass from which it was produced have been compared directly (Keady et al., 1999).

\section{Fatty Acid Composition of the Milk Fat}

The fatty acid composition of the raw milk from cows on the IC and PS diets at d 14 of the trial are detailed in Table 2. The PS diet resulted in an increase in linoleic acid in the milk fat $(P<0.001)$. This was due to high levels of linoleic acid in the sunflower oil. Other fatty acids were also affected in the milk from the PS diet, compared with that produced on the IC diet, as a result of the combination of pasture feeding and sunflower oil supplementation. There was a decrease $(P<0.01)$ in the concentration of short-chain fatty acids, with the exception of butyric acid (C4:0), which remained constant, and there was an increase $(P<0.01)$ in the con- centration of long-chain fatty acids, with the exception of linolenic acid, which remained constant between the IC and PS diets (Table 2). There was a decrease $(P<$ $0.001)$ in the palmitic acid (C16:0) concentration and an increase in the stearic acid (C18:0) concentration in the PS milk compared with the IC milk $(P<0.001)$. These changes in fatty acid profile are similar to those observed previously on grass- and silage-based diets (Murphy, 2000). There were large increases $(P<0.001)$ in the concentrations of C18:1 trans-9 plus C18:1 trans11 (TVA), and in the concentrations of C18:1 trans -13 plus C18:1 cis-9 (oleic acid) in the PS milk compared with the IC milk. In this trial the effect of the diets on the concentration of cis-9, trans-11 CLA in milk was of primary interest. Although this experimental design could not separate the impacts of pasture and the sup-

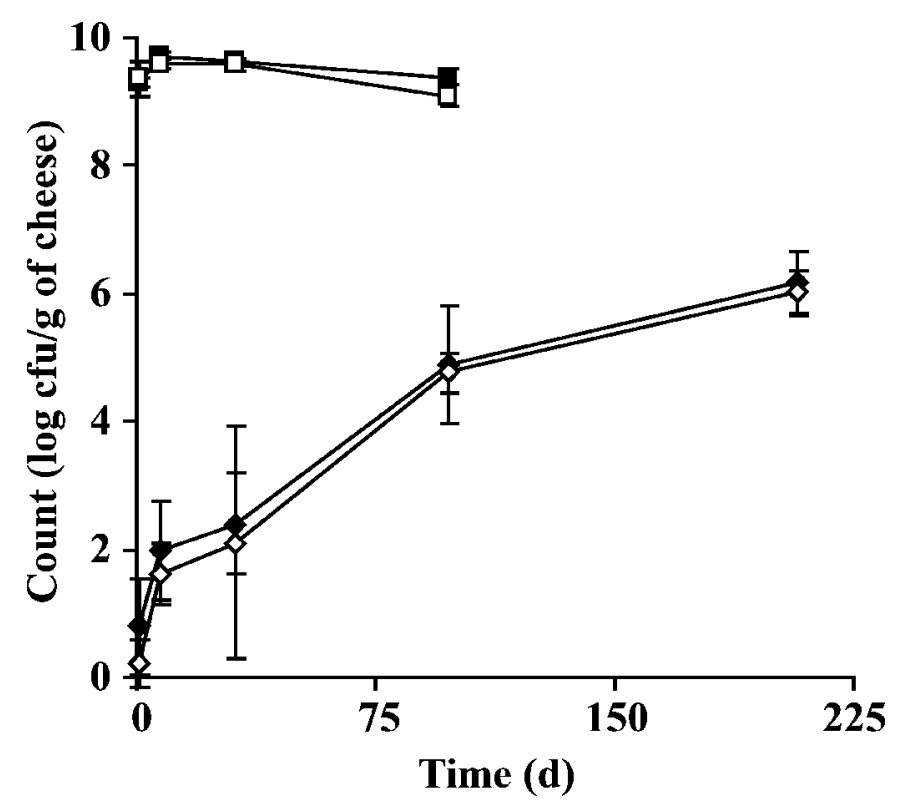

Figure 1. Microbiological analysis of the cheese over the ripening period. Levels of starter bacteria in the control ( $\square$ ) and elevated ( $\square$ )conjugated linoleic acid (CLA) cheese and levels of nonstarter lactic acid bacteria (NSLAB) in control $(\diamond)$ and elevated $(\diamond)$ CLA cheese. Values presented are mean \pm standard deviation of triplicate analyses. 
Table 4. Composition of control (IC) and elevated-conjugated linoleic acid (PS) cheese at mo 1 of ripening

\begin{tabular}{|c|c|c|c|c|c|c|}
\hline Cheese & $\begin{array}{l}\text { Moisture } \\
\text { (\% wt/wt) }\end{array}$ & $\begin{array}{c}\text { Fat } \\
(\% \text { wt } / w t)\end{array}$ & $\begin{array}{c}\mathrm{FDM}^{1} \\
(\% \mathrm{wt} / \mathrm{wt})\end{array}$ & $\begin{array}{l}\text { Protein } \\
\text { (\% wt/wt) }\end{array}$ & $\begin{array}{c}\text { Salt } \\
(\% \text { wt/wt })\end{array}$ & $\mathrm{pH}$ \\
\hline & \multicolumn{6}{|c|}{ Mean \pm SD } \\
\hline IC & $39.79 \pm 0.38$ & $28.95 \pm 0.16$ & $48.09 \pm 0.29$ & $26.32 \pm 0.41$ & $1.34 \pm 0.15$ & $5.06 \pm 0.10$ \\
\hline PS & $39.27 \pm 1.12$ & $29.18 \pm 0.56$ & $48.04 \pm 0.50$ & $26.15 \pm 0.42$ & $1.31 \pm 0.22$ & $5.04 \pm 0.05$ \\
\hline
\end{tabular}

${ }^{1} \mathrm{FDM}=$ fat in $\mathrm{DM}$

plement on CLA, the results clearly demonstrate that the PS diet (pasture plus supplement) was effective at increasing the concentration of the biologically active cis-9, trans-11 CLA isomer in the raw milk. At d 14, the concentration of $c i s-9$, trans-11 CLA in the PS milk was almost 5-fold greater than that in the IC milk (2.22 and $0.46 \mathrm{~g} / 100 \mathrm{~g}$ of FAME, respectively, $P<0.001$ ). These results confirm the beneficial effects of pasture and sunflower oil on the milk CLA content observed in previous studies (Kelly et al., 1998; Kay et al., 2004).

\section{Physical and Chemical Properties of Control and Elevated-CLA Cheese}

Cheese-Making Properties of the Milk During Cheese Manufacture. During cheese manufacture, there were no recorded differences between dietary treatments with respect to coagulation time, rate of acidification, or rate of firming of the cheese (data not shown). Also, the quantity of curd recovered at the end of cheese making for the control and elevated-CLA milk were not significantly different. The control milk yielded $10.4 \pm 0.6 \%$ (mean \pm standard deviation) curd from the cheese milk, and the elevated-CLA cheese milk yielded $10.9 \pm 0.2 \%$ curd from the cheese milk during triplicate cheese-making trials. Assessment of the bulk raw milk samples prior to cheese making revealed a decrease in milk fat concentrations caused by sunflower supplementation on pasture, in agreement with the results of Kay et al. (2004; Table 3). However, following standardization of the fat-to-protein ratio during the cheese-making process, the concentration of fat in the milk was more uniform $(3.11 \%$ in the control milk compared with $3.29 \%$ in the experimental milk). The protein and lactose concentrations were not adjusted because of the standardization process. Standardization did alter the cis-9, trans-11 CLA concentration in the milk fat; however, a substantial difference was still recorded between the control and elevated-CLA cheese following cheese making $(0.78$ and $1.93 \mathrm{~g} / 100 \mathrm{~g}$ of FAME at $d 1$, respectively).

Microbiology of the Cheese. The numbers of starter bacteria and NSLAB in the cheese are detailed in Figure 1 . The starter population was $\sim 10^{9} \mathrm{cfu} / \mathrm{g}$ of cheese at $d$ of cheese making and was stable up to mo 3 , when monitoring of the starter bacterial numbers ceased. The NSLAB population was low at d $1\left(\sim 10^{0}\right.$ to $10^{1} \mathrm{cfu} / \mathrm{g}$ of cheese) and increased during ripening, up to $\sim 10^{5} \mathrm{cfu} /$ $\mathrm{g}$ cheese at mo 6 . The numbers of starter bacteria and NSLAB in the elevated-CLA cheese followed the trend of the control cheese. Thus, elevating the cis-9, trans11 CLA level in the cheese did not affect the growth of starter bacteria or NSLAB in the cheese during ripening.

Cheese Composition. There was no noteworthy difference in the composition of the control and elevatedCLA cheese at mo 1 of the ripening period (Table 4), indicating that the different diets did not affect the composition of the cheese.

Cheese Fatty Acid Composition. The fatty acid composition of the control and the elevated-CLA cheese at various time points during the ripening period $(\mathrm{d} 1$, mo 1 , mo 3, and mo 6) is outlined in Table 5. The fatty acid profile of the cheese was similar to that of the raw milk from which it was produced prior to standardization, as was found by Dhiman et al. (1999). The concentration of cis-9, trans-11 CLA in the control and elevated-CLA cheese during ripening is shown in Figure 2 . The cis-9, trans-11 CLA was stable during the 6-mo ripening period $(0.78$ and $1.93 \mathrm{~g} / 100 \mathrm{~g}$ of FAME at $\mathrm{d} 1$ and 0.76 and $1.84 \mathrm{~g} / 100 \mathrm{~g}$ of FAME at mo 6 , in the control and elevated CLA groups, respectively). Even higher concentrations of CLA could have been achieved in the cheese if the concentration of $c i s-9$, trans-11 CLA did not decrease upon standardization, as a result of using nontrial milk and cream for standardization. The concentration of TVA also increased significantly $(P<$ 0.001 ) in both the milk and cheese because of the sunflower-supplemented pasture diet, with a 2.5 -fold increase (up to $6.7 \mathrm{~g}$ of TVA/100 $\mathrm{g}$ of FAME) at $\mathrm{d} 1$, which was maintained during the ripening period. The CLA intake required to prevent cancer and to have an impact on human health in general is still unknown. Recent human studies have demonstrated beneficial effects of cis-9, trans-11 CLA on human health, at concentrations of $>1.2 \mathrm{~g}$ of cis-9, trans-11 CLA/d (Tricon et al., 2004), whereas animal studies suggest that as little as $0.8 \mathrm{~g}$ of cis-9, trans-11 CLA/d may be sufficient for tumor inhibition (Watkins and Li, 2003). The cheese manufactured at pilot scale in this study contained $0.51 \mathrm{~g}$ of $\mathrm{cis}$ - 
Table 5. Fatty acid concentrations in the control and elevated-conjugated linoleic acid (CLA) cheese at $d$, mo 1, mo 3 , and mo 6 of the ripening period

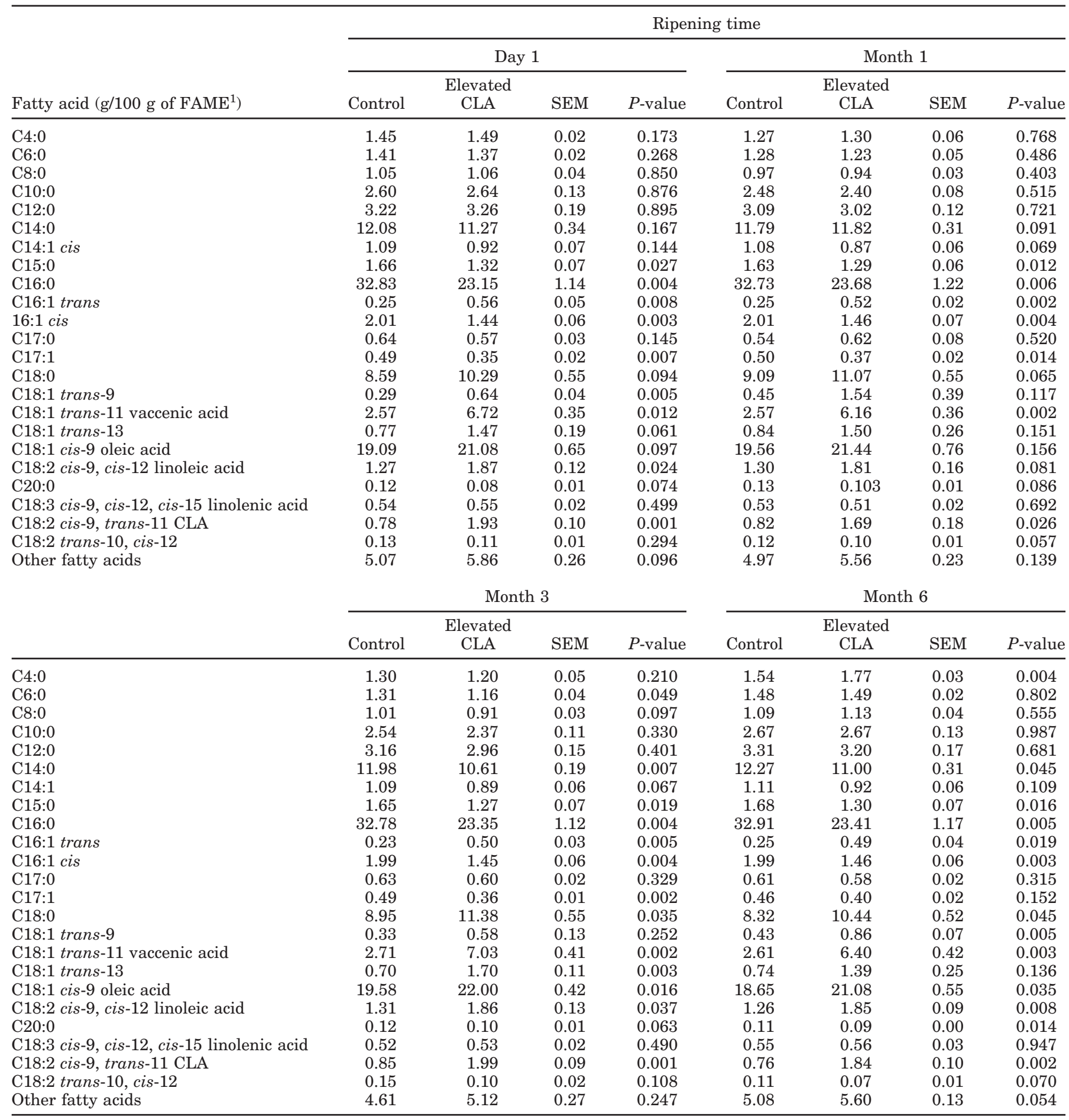

${ }^{1} \mathrm{FAME}=$ fatty acid methyl esters.

9, trans-11 CLA/100 g of cheese at mo 6 . This concentration of CLA, in combination with the concentration of TVA (1.8 $\mathrm{g}$ of TVA/100 $\mathrm{g}$ of cheese at mo 6 ), some of which may be converted to CLA, would contribute sig- nificantly to the $c i s-9$, trans-11 CLA status in humans, thus contributing to improved human health.

Grading of the Cheese. The cheese was presented for commercial grading after 6 mo of ripening to com- 


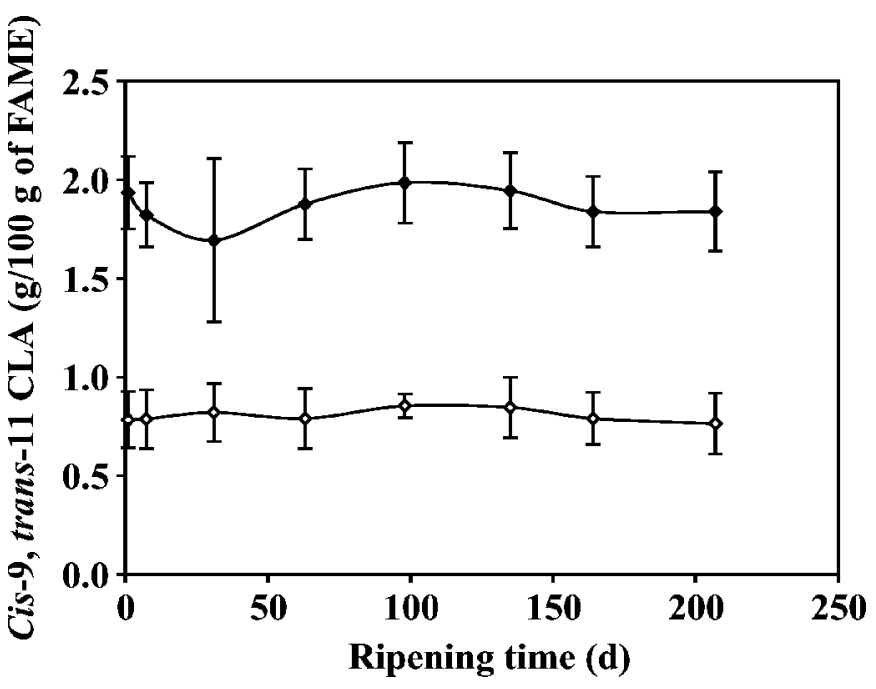

Figure 2. $C i s-9$, trans-11 conjugated linoleic acid (CLA) concentrations in control $(\diamond)$ and elevated-CLA $(\diamond)$ cheese during ripening. As the 6-mo ripening period progressed, the CLA concentrations remained constant in the cheese, with concentrations at mo 6 of 0.76 (control) and 1.84 (CLA-enriched) $\mathrm{g} / 100 \mathrm{~g}$ of fatty acid methyl esters (FAME). Values presented are mean \pm standard deviation of triplicate analyses.

pare the effects of dietary supplementation on quality characteristics and sensory criteria. The grading indicated that the control and elevated CLA cheese were acceptable with respect to sensory criteria (Table 6).

\section{CONCLUSIONS}

This study illustrates that the concentration of the potential health-promoting fatty acid cis-9, trans-11 CLA was substantially greater in the milk from cows on pasture supplemented with sunflower oil than in the milk from cows indoors on a grass and silage-based diet. The concentration of $c i s-9$, trans-11 CLA increased in the sunflower oil-fed group on pasture by $\mathrm{d} 14$ of the trial, to $2.22 \mathrm{~g} / 100 \mathrm{~g}$ of FAME, compared with $0.46 \mathrm{~g} /$ $100 \mathrm{~g}$ of FAME in the milk of control cows. Enhancing the cis-9, trans-11 CLA concentration of the milk resulted in cheese with enhanced cis-9, trans-11 CLA concentrations $(1.93 \mathrm{~g} / 100 \mathrm{~g}$ of FAME compared with 0.78 $\mathrm{g} / 100 \mathrm{~g}$ of FAME in the control) being manufactured at

Table 6. Assessment of cheese at mo $6(\text { mean } \pm \text { SD })^{1}$ by a commercial grader

\begin{tabular}{lcc}
\hline Cheese & Flavor & Body \\
\hline Control & $39.0 \pm 0.6$ & $32.0 \pm 0.0$ \\
Elevated CLA & $40.0 \pm 1.5$ & $32.0 \pm 0.0$ \\
\hline
\end{tabular}

\footnotetext{
${ }^{1}$ Mean \pm SD of triplicate cheese making. Minimum acceptable values for flavor and body are 37 and 30, respectively. CLA = conjugated linoleic acid.
}

pilot scale. This cheese actually contained $0.54 \mathrm{~g}$ of $\mathrm{cis}$ 9, trans-11 CLA/100 g of cheese (compared with $0.22 \mathrm{~g}$ of cis-9, trans-11 CLA/100 g of control cheese) at manufacture, and from a consumer health viewpoint, this cheese would contribute to the level of CLA being ingested by humans on a daily basis. The concentration of TVA, a precursor of CLA, in the milk and thus the cheese was also greater on the diet of pasture and sunflower oil. The cheese produced in this study had acceptable production and sensory characteristics.

\section{ACKNOWLEDGMENTS}

This work was funded by European Union Project QLK1-2002-02362, the Irish Government under the National Development Plan 2000-2006, and by Science Foundation Ireland funds. The technical assistance of Brendan Kavanagh, Christina Fleming, Des Eason, Eddie Mulholland, Jonathan Kenneally, Paula O'Connor, and Seamus Aherne is gratefully acknowledged. Thanks to Pat Fenton, Dairygold (Cork, Ireland), for grading the cheese.

\section{REFERENCES}

Aneja, R. P., and T. N. Murthi. 1990. Conjugated linoleic acid contents of Indian curds and ghee. Ind. J. Dairy Sci. 43:231-238.

Bauman, D. E., D. M. Barbano, D. A. Dwyer, and J. M. Griinari. 2000. Technical note: Production of butter with enhanced conjugated linoleic acid for use in biomedical studies with animal models. J. Dairy Sci. 83:2422-2425.

Bauman, D. E., and J. M. Griinari. 2001. Regulation and nutritional manipulation of milk fat: Low-fat milk syndrome. Livest. Prod. Sci. 70:15-29

Bauman, D. E., and J. H. Griinari. 2003. Nutritional regulation of milk fat synthesis. Annu. Rev. Nutr. 23:203-227.

Chilliard, Y., J. M. Chardingy, J. Chabrot, A. Ollier, J. L. Sébédio, and M. Doreau. 1999. Effects of ruminal or postruminal fish oil supply on conjugated linoleic acid (CLA) content of cow milk fat. Proc. Nutr. Soc. 58:70A.

Davis, C. L., and R. E. Brown. 1970. Low-fat milk syndrome. Pages 545-565 in Physiology of Digestion and Metabolism in the Ruminant. A. T. Phillipson, ed. Oriel Press, Newcastle upon Tyne, UK.

Dhiman, T. R., E. D. Helmink, D. J. McMahon, R. L. Fife, and M. W. Pariza. 1999. Conjugated linoleic acid content of milk and cheese from cows fed extruded oilseeds. J. Dairy Sci. 82:412-419.

Dhiman, T. R., L. D. Satter, M. W. Pariza, M. P. Gali, K. Albright, and M. X. Tolosa. 2000. Conjugated linoleic acid (CLA) content of milk from cows offered diets rich in linoleic and linolenic acid. J. Dairy Sci. 83:1016-1027.

Garcia Lopez, S., E. Echeverria, I. Tsui, and B. Balch. 1994. Changes in the content of conjugated linoleic acid (CLA) in processed cheese during processing. Food Res. Int. 27:61-64.

Griinari, J. M., and D. E. Bauman. 1999. Biosynthesis of conjugated linoleic acid and its incorporation into meat and milk in ruminants. Pages 180-200 in Advances in Conjugated Linoleic Acid Research. Vol. 1. M. P. Yurawecz, M. M. Mossoba, J. K. G. Kramer, M. W. Pariza, and G. J. Nelson, ed. AOCS Press, Champaign, IL. Griinari, J. M., B. A. Corl, S. H. Lacy, P. Y. Chouinard, K. V. V. Nurmela, and D. E. Bauman. 2000. Conjugated linoleic acid is synthesized endogenously in lactating dairy cows by $\Delta^{9}$-desaturase. J. Nutr. 130:2285-2291.

IDF (International Dairy Federation). 1986. Determination of fat content-Gravimetric method (cheese and processed cheeses products). IDF Standard 5B. IDF, Brussels, Belgium. 
IDF (International Dairy Federation). 1988. Determination of chloride content-Potentiometric titration method (cheese and processed cheese products). IDF Standard 88A. IDF, Brussels, Belgium.

IDF (International Dairy Federation). 1993. Milk. Determination of the nitrogen content (Kjeldahl method) and calculation of crude protein content. IDF Standard 20B. IDF, Brussels, Belgium.

IDF (International Dairy Federation). 2000. Whole milk-Determination of milk-fat, protein and lactose content (guidance for the operation of mid-infrared instruments) IDF Standard 141C. IDF, Brussels, Belgium.

Jiang, J., L. Björck, and R. Fonden. 1997. Conjugated linoleic acid in Swedish dairy products with special reference to manufacture of hard cheeses. Int. Dairy J. 7:863-867.

Jiang, J., L. Björck, and R. Fonden. 1998. Production of conjugated linoleic acid by dairy starter cultures. J. Appl. Microbiol. 85:95-102.

Jones, L., K. J. Shingfield, C. K. Kohen, A. Jones, B. Lupoli, A. S. Grandison, D. E. Beever, C. M. Williams, P. C. Calder, and P. Yaqoob. 2005. Chemical, physical, and sensory properties of dairy products enriched with conjugated linoleic acid. J. Dairy Sci. 88:2923-2937.

Kay, J. K., T. R. Mackle, M. J. Auldist, N. A. Thomson, and D. E. Bauman. 2004. Endogenous synthesis of cis-9, trans-11 conjugated linoleic acid in dairy cows fed fresh pasture. J. Dairy Sci. 87:369-378.

Keady, T. W. J., J. J. Murphy, and D. Harrington. 1999. The effects of ensiling on dry-matter intake and milk production by lactating dairy cattle given forage as the sole feed. Grass Forage Sci. 51:131-141.

Kelly, M. L., J. R. Berry, D. A. Dwyer, J. M. Griinari, P. Y. Chouinard, M. E. Van Amburgh, and D. E. Bauman. 1998. Dietary fatty acid sources affect conjugated linoleic acid concentrations in milk from lactating dairy cows. J. Nutr. 128:881-885.

Kepler, C. R., K. P. Hirons, J. J. McNeill, and S. B. Tove. 1966. Intermediates and products of the biohydrogenation of linoleic acid by Butyrivibrio fibrisolvens. J. Biol. Chem. 241:1350-1354.

Khanal, R. C., T. R. Dhiman, A. L. Ure, C. P. Brennand, R. L. Boman, and D. J. McMahon. 2005. Consumer acceptability of conjugated linoleic acid-enriched milk and Cheddar cheese from cows grazing on pasture. J. Dairy Sci. 88:1837-1847.

Khanal, R. C., and K. C. Olson. 2004. Factors affecting conjugated linoleic acid (CLA) content in milk, meat, and egg: A review. Pak. J. Nutr. 3:82-98.

Lin, H., T. D. Boylston, L. O. Luedecke, and T. D. Shultz. 1998. Factors affecting the conjugated linoleic acid content of Cheddar cheese. J. Agric. Food Chem. 46:801-807.

Lock, A. L., and P. C. Garnsworthy. 2002. Independent effects of dietary linoleic and linolenic fatty acids on the conjugated linoleic acid content of cows' milk. Anim. Sci. 74:163-176.

Lynch, J. M., A. L. Lock, D. A. Dwyer, R. Noorbakhsh, D. M. Barbano, and D. E. Bauman. 2005. Flavor and stability of pasteurized milk with elevated levels of conjugated linoleic acid and vaccenic acid. J. Dairy Sci. 88:489-498.

McNamara, S., F. P. O'Mara, M. Rath, and J. J. Murphy. 2003. Effects of different transition diets on dry matter intake, milk production, and milk composition in dairy cows. J. Dairy Sci. 86:2397-2408.

Murphy, J. J. 2000. Synthesis of milk fat and opportunities for nutritional manipulation. Br. Soc. Anim. Sci. Occ. Publ. No. 25:201222

Murphy, J. J., G. P. McNeill, J. F. Connolly, and P. A. Gleeson. 1990. Effect on cow performance and milk fat composition of including full fat soybean and rapeseed in the concentrate mixture for lactating dairy cows. J. Dairy Res. 57:295-306.

Parodi, P. W. 2003. Conjugated linoleic acid in food. Pages 101-122 in Advances in Conjugated Linoleic Acid Research. Vol. 2. J. L. Sébédio, W. W. Christie, and R. Adlof, ed. AOCS Press, Champaign, IL.

Ramaswamy, N., R. J. Baer, D. J. Schingoethe, A. R. Hippen, K. M. Kasperson, and L. A. Whitlock. 2001. Composition and flavor of milk and butter from cows fed fish oil, extruded soybeans, or their combination. J. Dairy Sci. 84:2144-2151.

Ryan, M. P., M. C. Rea, C. Hill, and R. P. Ross. 1996. An application in Cheddar cheese manufacture for a strain of Lactococcus lactis producing a novel broad-spectrum bacteriocin, lacticin 3147. Appl. Environ. Microbiol. 62:612-619.

Shantha, N. C., E. A. Decker, and Z. Ustunol. 1992. Conjugated linoleic acid concentration in processed cheese. J. Am. Oil Chem. Soc. 69:425-428.

Stanton, C., F. Lawless, G. Kjellmer, D. Harrington, R. Devery, J. F Connolly, and J. Murphy. 1997. Dietary influences on bovine milk cis-9, trans-11-conjugated linoleic acid content. J. Food Sci. 62:1083-1086.

Stanton, C., J. Murphy, E. McGrath, and R. Devery. 2003. Animal feeding strategies for conjugated linoleic acid enrichment of milk. Pages 123-145 in Advances in Conjugated Linoleic Acid Research. Vol. 2. J. L. Sébédio, W. W. Christie, and R. Adlof, ed. AOCS Press, Champaign, IL.

Tricon, S., G. C. Burdge, S. Kew, T. Banerjee, J. J. Russell, R. F. Grimble, C. M. Williams, P. C. Calder, and P. Yaqoob. 2004. Effects of cis-9, trans-11 and trans-10, cis-12 conjugated linoleic acid on immune cell function in healthy humans. Am. J. Clin. Nutr. 80:1626-1633.

Wahle, K. W., S. D. Heys, and D. Rotondo. 2004. Conjugated linoleic acids: Are they beneficial or detrimental to health? Prog. Lipid Res. 43:553-587.

Watkins, B. A., and Y. Li. 2003. CLA in functional foods: Enrichment of animal products. Pages 174-188 in Advances in Conjugated Linoleic Acid Research. Vol. 2. J. L. Sébédio, W. W. Christie, and R. Adolf, ed. AOCS Press, Champaign, IL.

Zlatanos, S., K. Lascaridis, C. Feist, and A. Sagredos. 2002. CLA content and fatty acids composition of Greek Feta and hard cheeses. Food Chem. 78:471-477. 